ISSN 1678-3921

Journal homepage: www.embrapa.br/pab

For manuscript submission and journal contents, access: www.scielo.br/pab

\section{Growth, antioxidant system, and immunological status of shrimp in bioflocs and clear water culture systems}

\begin{abstract}
The objective of this work was to evaluate the effect of the traditional culture system in clear water and of the one in microbial flocs on the antioxidant and immunological status of Litopenaeus vannamei shrimp. Samples (gill, hemolymph, and hepatopancreas) were collected on days 15, 30, and 60 of the experimental period. The following immunological parameters were analyzed at each evaluation time: granular and hyaline hemocytes, total protein, and apoptosis. Assays on glutamate-cysteine ligase (GCL) activity and on the concentrations of reduced glutathione (GSH) and thiobarbituric acid reactive substances (TBARS) were also performed. The evaluated immunological parameters did not differ significantly between treatments. Shrimp reared in clear water showed higher levels of lipid peroxidation in the gills and of GCL activity in the hemolymph on days 15 and 30. Shrimp in microbial floc had a higher survival rate, and the water did not have to be renewed during the experimental period. The microbial floc system improves production levels and provides a healthier culture environment.
\end{abstract}

Index terms: Litopenaeus vannamei, BFT, oxidative stress, TBARS.

\section{Crescimento, sistema antioxidante e estado imunológico do camarão nos sistemas de cultivo em bioflocos e água clara}

Resumo - O objetivo deste trabalho foi avaliar o efeito do sistema de cultivo tradicional em água clara e do em bioflocos sobre os estados antioxidante e imunológico do camarão Litopenaeus vannamei. Amostras (brânquia, hemolinfa e hepatopâncreas) foram coletadas nos dias 15, 30 e 60 do período experimental. Os seguintes parâmetros imunológicos foram analisados a cada tempo amostral: hemócitos granulares e hialinos, proteína total e apoptose. Também foram realizados ensaios da atividade da glutamato-cisteína ligase (GCL) e das concentrações de glutationa reduzida (GSH) e de substâncias reativas ao ácido tiobarbitúrico (TBARS). Os parâmetros imunológicos avaliados não diferiram significativamente entre os tratamentos. Os camarões criados em água clara apresentaram maiores níveis de peroxidação lipídica nas brânquias e de GCL na hemolinfa nos dias 15 e 30. Camarões em bioflocos apresentaram maior taxa de sobrevivência, e a água não precisou ser renovada durante o período experimental. O sistema de bioflocos melhora os níveis de produtividade e promove um ambiente de cultivo mais saudável.

Termos para indexação: Litopenaeus vannamei, BFT, estresse oxidativo, TBARS. 


\section{Introduction}

Aquaculture has increased substantially over the years. Shrimp now ranks second in terms of value, being responsible for $15 \%$ of the total value of internationally traded fishery products in 2012 (FAO, 2016). Litopenaeus vannamei is the penaeid shrimp species most cultured worldwide. In the 1980s, shrimp production, in the traditional system in clear water, was performed with low stocking density in ponds with a high surface area and a great amount of water use and discharge, which not only caused negative environmental impacts, but also economic losses. Subsequently, alternative strategies were developed to increase shrimp production and turn shrimp culture into an environmentally friendly activity. These strategies include: fertilization, use of feeding trays, increased stocking densities, and the use of the biofloc technology (BFT) system (Wasielesky Jr. et al., 2006).

BFT is a shrimp production system based on the manipulation of a microbial community through the addition of a carbon source that promotes the development of heterotrophic bacteria (Souza et al., 2014). One of the benefits of this system is the bacterial uptake of nitrogen, including ammonia, and its ulterior conversion into cellular protein, providing a supplemental source of nutrition (Burford et al., 2004; Wasielesky Jr. et al., 2006) and possibly reducing the demand for protein in feed. Another important advantage is there is no water exchange, which drastically reduces water use and also avoids the damage caused by the release of effluents to the environment (Souza et al., 2014). The assimilation of nitrogen compounds by heterotrophic bacteria in BFT allows the same water to be used for several production cycles with no negative environmental impact (Krummenauer, 2014). In addition, the BFT system can promote an enhancement in the immune cellular response and antioxidant status of shrimp (Xu \& Pan, 2013; Martins et al., 2015). The immune and antioxidant systems play an important role in animal physiology and are crucial to control their health and growth performance.

The antioxidant system is also fundamental in the protection against damage due to reactive oxygen species, which includes lipid peroxidation (LPO), a form of oxidative damage usually quantified by determining the content of thiobarbituric acid reactive substances (TBARS) in tissues (Oakes \& Van der Kraak, 2003).
Because glutamate-cysteine ligase (GCL) is a major determinant of the levels of the cellular antioxidant reduced glutathione (GSH), studies have investigated its activity in several aquatic organisms (LongarayGarcia et al., 2013; Souza et al., 2016).

The objective of this work was to evaluate the effect of the traditional culture system in clear water and of the one in microbial flocs on the antioxidant and immunological status of Litopenaeus vannamei shrimp.

\section{Materials and Methods}

A 60-day trial was conducted at the marine aquaculture station at Universidade Federal do Rio Grande, located in the state of Rio Grande do Sul, in Southern Brazil $\left(32^{\circ} .12^{\prime} 13.5^{\prime \prime} \mathrm{S}, 52^{\circ} .10^{\prime} 40.3^{\prime \prime} \mathrm{W}\right)$. The experimental system consisted of six 200-L tanks assigned to the following treatments: BFT and clear water $(\mathrm{CW})$ at $27^{\circ} \mathrm{C}$ and salinity of $30 \mathrm{~g} \mathrm{~L}^{-1}$. Litopenaeus vannamei, weighing $1.91 \pm 0.22$ and $2.26 \pm 0.24 \mathrm{~g}$ for BFT and CW, respectively, were acclimatized for ten days and stocked at a density of 111 shrimp per square meter. To promote the development of the microbial flocs, BFT tanks received an inoculum of $75 \mathrm{~L}$ from a heterotrophic shrimp culture, as adapted from Souza et al. (2012). The animals were fed twice daily, via a feeding tray, with feed containing $38 \%$ crude protein (Wasielesky Jr. et al., 2006).

The water from the $\mathrm{CW}$ treatment was renewed approximately $70 \%$ every three days to avoid the increase of ammonia. When ammonia reached 1 $\mathrm{mg} \mathrm{L}^{-1}$ in the BFT tanks, a molasses dose calculated according to Ebeling et al. (2006) and Avnimelech (1999) was applied. At the end of the experimental period, the following were evaluated: survival, as the final number of shrimp/initial number of shrimp $\mathrm{x} 100$; final weight; specific growth rate, as $(\ln$ (final weight) - $\ln$ (initial weight))/trial duration $\times 100$; and productivity, as total biomass/water volume.

Throughout the experimental period, the following water quality parameters were recorded daily: water temperature, salinity, $\mathrm{pH}$, and dissolved oxygen. Water samples were collected three times a week to determine the concentrations of total ammonia (Chemical methods..., 1983) and nitrite (Bendschneider \& Robinson, 1952). Alkalinity and nitrate were monitored once a week as proposed by Chemical methods... (1983) and Baumgarten et al. (1996), respectively. Total 
suspended solids (TSS) were evaluated following the methodology adapted from Strickland \& Parsons (1972).

For the immunological analysis, hemolymph was collected at 30 and 60 days directly from the heart of six shrimp per treatment using sterile syringes (Söderhäll $\&$ Smith, 1983). Granular and hyaline hemocytes were counted with a Neubauer chamber (Maggioni et al., 2004). Total protein concentration in the serum of six shrimp per treatment was determined according to the method of Bradford (1976), using bovine serum albumin as a standard (Maggioni et al., 2004). For the detection of apoptosis, $5 \mu \mathrm{L}$ shrimp hemolymph were smeared onto a clean glass slide and air-dried; five clean slides were used per treatment. Apoptotic hemocytes were counted by Tunel staining with the ApopTag ${ }^{\circledR}$ Plus Peroxidase In Situ Apoptosis Detection Kit (EMD Millipore Corporation, Temecula, CA, USA) according to Charriaut-Marlangue \& Ben-Ari (1995) and Wang \& Zhang (2008).

For the antioxidant system analysis, the hemolymph, gills, and hepatopancreas of nine shrimp per treatment were sampled randomly on days 15,30 , and 60 . For protein quantification and the antioxidant enzyme analysis, hemolymph was centrifuged twice to obtain a pellet or cell lysate. After centrifugation, the cell lysate was resuspended in a buffer solution and stored in an ultra-low freezer (Souza et al., 2016). The samples from the gills and hepatopancreas were weighed and then added at a ratio of 1:5 to a buffer solution. Tissue samples were then centrifuged, and the supernatant was stored in an ultra-low freezer at $-80^{\circ} \mathrm{C}$. Total protein content was determined by the Biuret method using the "Proteínas Totais" commercial kit (Doles Reagentes e Equipamentos para Laboratórios Ltda., Goiânia, GO, Brazil) and read at $550 \mathrm{~nm}$ with the Victor2 microplate reader (PerkinElmer do Brasil Ltda., São Paulo, SP, Brazil).

GCL activity and GSH synthesis were determined according to White et al. (2003). The adopted method makes use of the reaction of naphthalene dicarboxaldehyde with GSH or $\gamma$-glutamylcysteine, forming fluorescent cyclic products that can be detected on the Victor2 fluorescence microplate reader (PerkinElmer do Brasil Ltda., São Paulo, SP, Brazil) at the wavelengths of 485 and $530 \mathrm{~nm}$ for excitation and emission, respectively. LPO was measured by determining TBARS, according to the methodology of Oakes \& Van Der Kraak (2003), measured by fluorescence at the wavelengths of 520 and $580 \mathrm{~nm}$ for excitation and emission, respectively. The concentration of lipid peroxides was expressed as nmol TBARS per milligram of protein, and tetramethoxypropane (Thermo Fisher Scientific, Acros Organics, Geel, Belgium) was used as a standard.

Data are given as the mean \pm standard error of the mean and were analyzed by the one-way analysis of variance, followed by the Newman-Keuls post-hoc mean comparison. Assumptions of normality and of homogeneity of variances were previously checked by the Kolmogorov-Smirnov and Levene tests, respectively. In all cases, results were considered to be significant at $5 \%$ probability.

\section{Results and Discussion}

Although significant differences were observed in $\mathrm{pH}$, salinity, alkalinity, total ammonia, nitrite, and nitrate between treatments, water quality parameters remained at concentrations suitable for shrimp culture in both studied systems (Table 1).

The values obtained for $\mathrm{pH}$ and alkalinity were lower in the BFT system than in the $\mathrm{CW}$ one. This was probably due to the respiration of heterotrophic organisms, which increased the carbon dioxide concentration in the water of the biofloc treatment, and to nitrification (Wasielesky Jr. et al., 2006; Furtado et al., 2011), as shown by the

Table 1. Water physicochemical parameters in the experimental tanks ${ }^{(1)}$.

\begin{tabular}{lcc}
\hline Parameter & \multicolumn{2}{c}{ Treatment } \\
\cline { 2 - 3 } & BFT at $27^{\circ} \mathrm{C}$ & $\mathrm{CW}$ at $27^{\circ} \mathrm{C}$ \\
\hline Temperature $\left({ }^{\circ} \mathrm{C}\right)$ & $26.89 \pm 0.15 \mathrm{a}$ & $26.73 \pm 0.09 \mathrm{a}$ \\
pH & $7.68 \pm 0.02 \mathrm{a}$ & $8.23 \pm 0.01 \mathrm{~b}$ \\
Salinity $\left(\mathrm{g} \mathrm{L}^{-1}\right)$ & $31.88 \pm 0.24 \mathrm{a}$ & $29.28 \pm 0.18 \mathrm{~b}$ \\
DO $\left(\mathrm{mg} \mathrm{L}^{-1}\right)$ & $5.91 \pm 0.03 \mathrm{a}$ & $6.13 \pm 0.02 \mathrm{a}$ \\
Alkalinity (mg L & $93.14 \pm 5.91 \mathrm{a}$ & $148.70 \pm 1.15 \mathrm{~b}$ \\
TAN $\left(\mathrm{mg} \mathrm{L}^{-1}\right)$ & $0.15 \pm 0.01 \mathrm{a}$ & $0.33 \pm 0.03 \mathrm{~b}$ \\
Nitrite $\left(\mathrm{mg} \mathrm{L}^{-1}\right)$ & $0.07 \pm 0.006 \mathrm{a}$ & $1.40 \pm 0.23 \mathrm{~b}$ \\
Nitrate $\left(\mathrm{mg} \mathrm{L}^{-1}\right)$ & $42.02 \pm 4.77 \mathrm{a}$ & $7.77 \pm 1.78 \mathrm{~b}$ \\
TSS $\left(\mathrm{mg} \mathrm{L}^{-1}\right)$ & $30 \pm 15.23 \mathrm{a}$ & $450 \pm 40.56 \mathrm{~b}$ \\
\hline
\end{tabular}

${ }^{(1)}$ Means followed by equal letters in the rows do not differ among treatments by the one-way analysis of variance, at $5 \%$ probability. DO, dissolved oxygen; TAN; total ammonia nitrogen; TSS, total suspended solids; BFT, biofloc technology; and $\mathrm{CW}$, clear water. Data are mean \pm standard error of the mean. 
higher level of nitrate in biofloc tanks. Total ammonia nitrogen (TAN) was also lower in BFT tanks due to the nitrification process performed by the microorganisms present in this system. This result is in agreement with those found by Ray et al. (2017), who tested shrimp culture in CW and BFT in a recirculating aquaculture system. The authors also reported higher levels of TAN in the $\mathrm{CW}$ treatment, showing that the microorganisms present in the BFT play an important role in controlling these levels.

Shrimp reared in the BFT system presented a survival rate of $73.33 \pm 1.4 \%$, higher than that of $59.16 \pm 3.0 \%$ of those reared in $\mathrm{CW}$ (Table 2). However, shrimp in CW showed a greater final weight, although specific growth rate did not differ between treatments. The improved performance (survival and productivity) of $L$. vannamei reared in BFT systems can be related to the consumption of bioflocs by the shrimp. According to Burford et al. (2004), up to $29 \%$ of the daily feed intake of this species can come from particles in heterotrophic culture systems. Therefore,

Table 2. Immunological and zootechnical parameters of Litopenaeus vannamei shrimp reared during a 60day experimental period (at 30 and 60 days) in biofloc technology (BFT) and clear water $(\mathrm{CW})$ systems at $27^{\circ} \mathrm{C}^{(1)}$.

\begin{tabular}{lccc}
\hline Parameter & $\begin{array}{c}\text { Period } \\
\text { (days) }\end{array}$ & \multicolumn{2}{c}{ Treatment } \\
\cline { 3 - 4 } & 30 & $66.2 \pm 2.2$ & $64.8 \pm 1.6$ \\
\hline GH, granular & 60 & $67.8 \pm 1.9$ & $69.2 \pm 2.1$ \\
hemocytes (\%) & 30 & $33.8 \pm 2.2$ & $35.2 \pm 1.5$ \\
HH, hyaline & 60 & $32.2 \pm 1.9$ & $30.8 \pm 2.1$ \\
hemocytes (\%) & 30 & $119.6 \pm 2.1$ & $119.2 \pm 1.2$ \\
TP & 60 & $119.4 \pm 1.0$ & $121.0 \pm 1.7$ \\
$(\mathrm{mg} \mathrm{mL}-1)$ & 30 & $2.0 \pm 0.3$ & $2.4 \pm .05$ \\
Apoptosis & 60 & $3.2 \pm 0.5$ & $2.6 \pm 0.6$ \\
$(\%)$ & & $73.33 \pm 1.4 \mathrm{a}$ & $59.16 \pm 3.0 \mathrm{~b}$ \\
SV (\%) & & $7.03 \pm 0.3 \mathrm{a}$ & $9.84 \pm 0.6 \mathrm{~b}$ \\
FW (g) & & $2.30 \pm 0.07 \mathrm{a}$ & $2.46 \pm 0.08 \mathrm{a}$ \\
SGR (\%) & & $0.95 \pm 0.2 \mathrm{a}$ & $0.19 \pm 0.3 \mathrm{~b}$ \\
Productivity $\left(\mathrm{kg} \mathrm{m}^{-3}\right)$ & & &
\end{tabular}

(1) Means followed by equal letters in the row do not differ among treatments by the one-way analysis of variance, at $5 \%$ probability. GH, granular hemocytes; HH, hyaline hemocytes; TP, total protein; SV survival; FW, final weight; and SGR, specific growth rate. Data are mean \pm standard error of the mean. the consumption of natural products and of other constituents of bioflocs by shrimp can increase the efficiency of feed use (Wasielesky Jr. et al., 2006; Emerenciano et al., 2012). Viau et al. (2013) confirmed that the consumption of microorganisms by shrimp represents a complementary food source.

No statistical differences were detected between treatments regarding immunological parameters (Table 2). Souza et al. (2014) also found no differences between treatments when assessing the immunological parameters hyaline and granular hemocyte count and total protein. It is assumed that the large concentration of bacteria associated with bioflocs may contribute to enhance the immunity and growth performance of shrimp when bioflocs are consumed (Kim et al., 2014); however, this was not observed in the present study.

The antioxidant system and TBARS levels differed significantly. Shrimp reared in the CW system on days 15 and 60 exhibited an increase of 431.04 and 4,193.80\%, respectively, in GCL activity in hemolymph, in comparison with those reared in BFT (Figure 1). On day 15, shrimp reared in the BFT system showed a higher GSH concentration of $252.70 \%$ than those reared in CW. A higher GCL activity of 364.15 and $234.60 \%$, respectively, was observed in the hepatopancreas of shrimp reared in the BFT system on days 15 and 30 (Figure 2). GSH synthesis is GCLactivity dependent and plays an important role against oxidative damages (Irvine, 1996). Zhang et al. (2007) reported that the addition of a suitable dose of GSH to the diet of tilapia improves the antioxidant capacity of muscle tissues and promotes their growth.

On day 30, shrimp reared in the $\mathrm{CW}$ system presented a higher level of $351.51 \%$ of TBARS in hemolymph. In gills, shrimp reared in the CW system showed a higher lipid peroxidation of $656.25 \%$ on day 15. It should be noted that LPO is one of the major outcomes associated with the failure of the antioxidant system (Castex et al., 2010). In the present work, the higher LPO in gills of shrimp reared in CW indicated a failure of the antioxidant system to counteract free radicals (Figure 3).

Based on its composition characteristics, bioflocs should present an antioxidant activity (Ju et al., 2008; Martins et al., 2015) and also stimulate digestive enzyme activities, improving feed utilization (Xu et al., 2013) and increasing dietary antioxidant assimilation. 

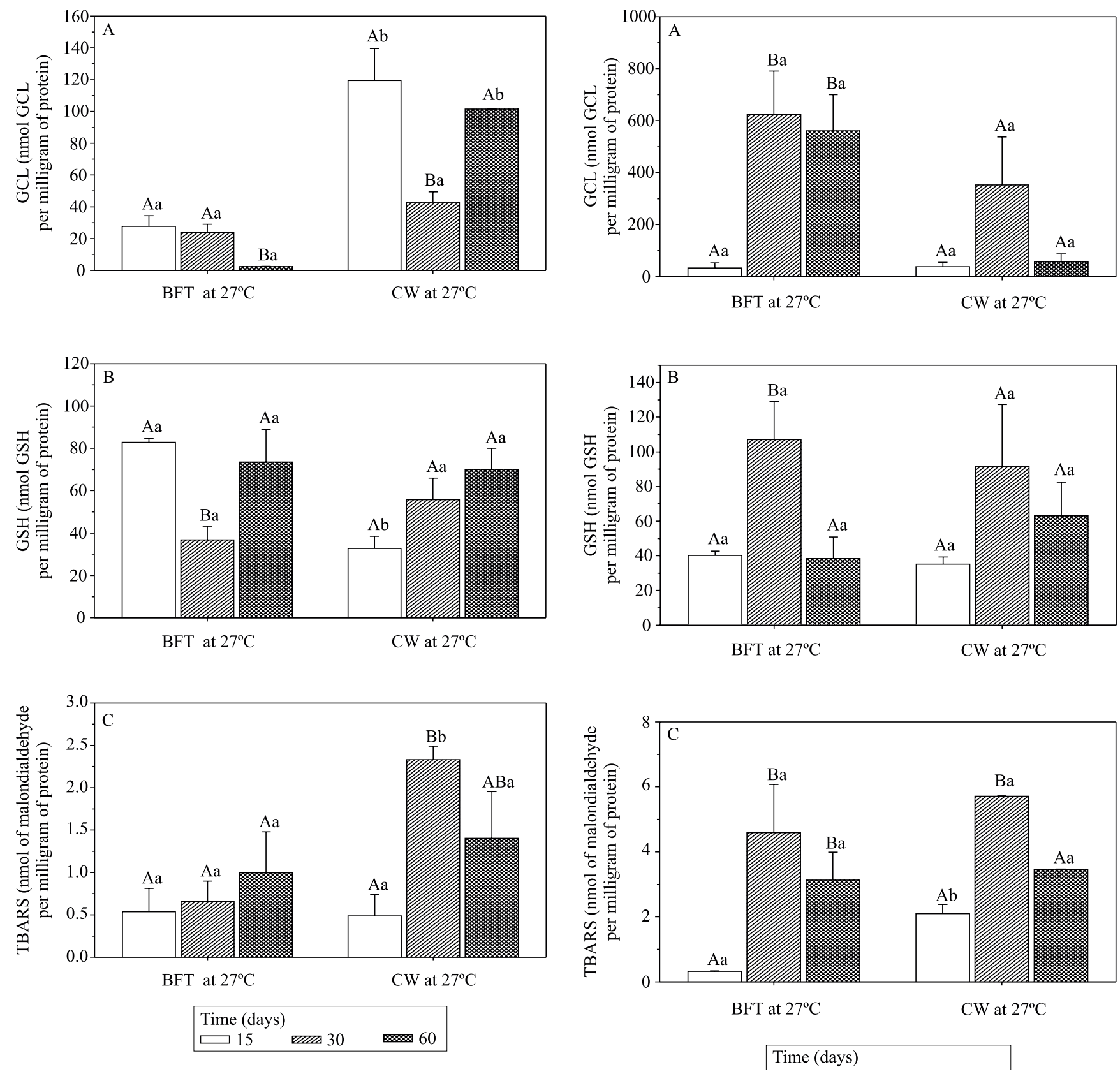

Figure 1. Glutamate-cysteine ligase (GCL) activity (A), reduced glutathione (GSH) concentration (B), and thiobarbituric acid reactive substances (TBARS) (C) in the hemolymph of Litopenaeus vannamei shrimp reared in biofloc technology (BFT) and clear water (CW) systems. Data are expressed as means \pm standard error of the mean. Different lowercase letters indicate significant differences between treatments over the same time period by the analysis of variance, followed by Newman-Keuls posthoc test, at $5 \%$ probability. Different uppercase letters indicate significant differences of each treatment over the experimental period.

Figure 2. Glutamate-cysteine ligase (GCL) activity (A), reduced glutathione (GSH) concentration (B), and thiobarbituric acid reactive substances (TBARS) (C) in the hepatopancreas of Litopenaeus vannamei shrimp reared in biofloc technology (BFT) and clear water (CW) systems. Data are expressed as means \pm standard error of the mean. Different lowercase letters indicate significant differences between treatments over the same time period by the analysis of variance, followed by Newman-Keuls post-hoc test, at $5 \%$ probability. Different uppercase letters indicate significant differences between each treatment over the experimental period. 

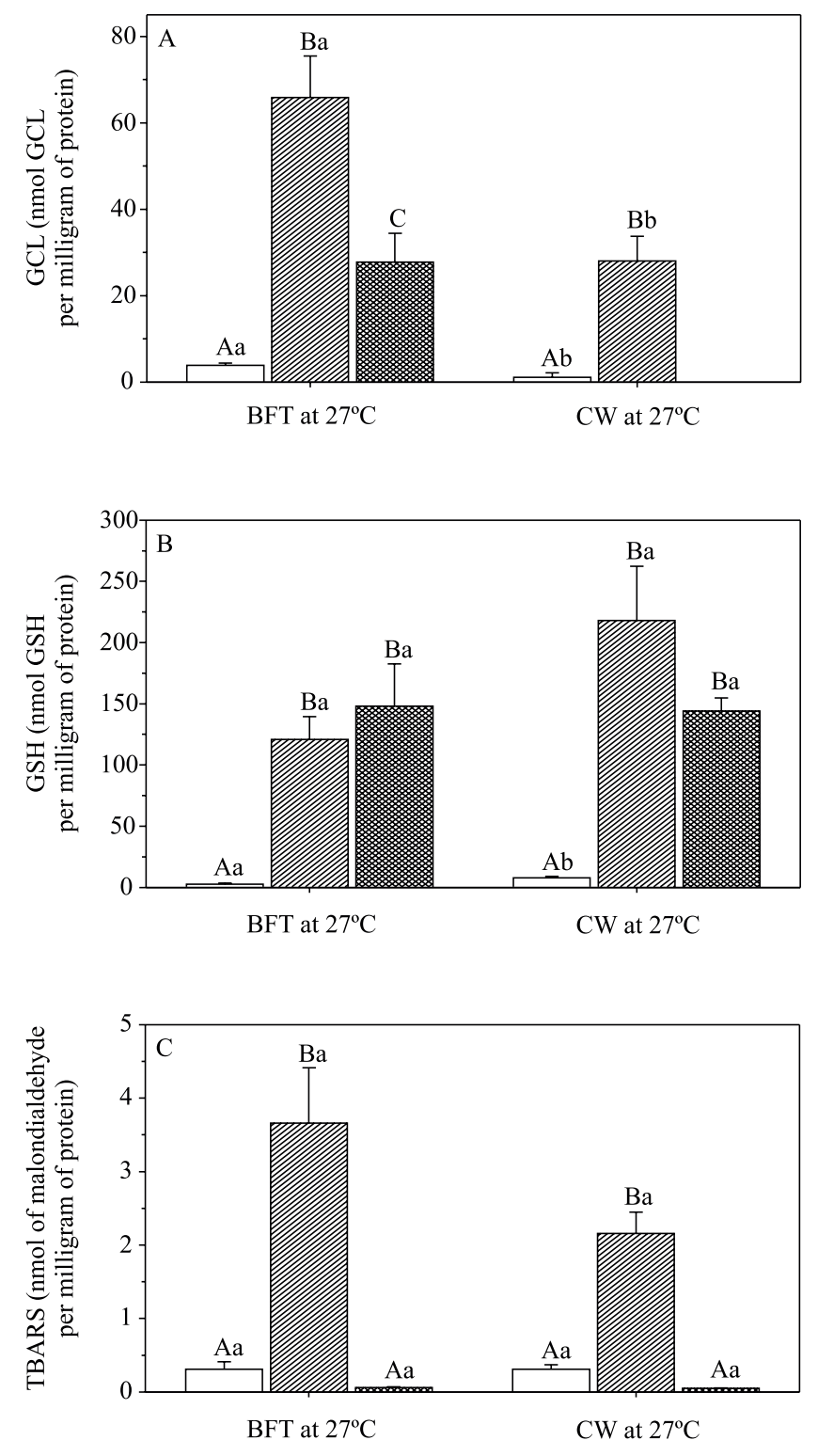

\begin{tabular}{|l|l|}
\hline \multicolumn{2}{l}{ Time (days) } \\
$\square 15 \quad 30 \quad 60$
\end{tabular}

Figure 3. Glutamate-cysteine ligase (GCL) activity (A), reduced glutathione (GSH) concentration (B), and thiobarbituric acid reactive substances (TBARS) (C) in the gills of Litopenaeus vannamei shrimp reared in biofloc technology (BFT) and clear water (CW) systems. Data are expressed as means \pm standard error of the mean. Different lowercase letters indicate significant differences between treatments over the same time period by the analysis of variance, followed by Newman-Keuls post-hoc test, at $5 \%$ probability. Different uppercase letters indicate significant differences between each treatment over the experimental period.
The BFT system presents many advantages that are applicable to shrimp farming, including zero water exchange. Currently, the concern worldwide is developing strategies to increase biosecurity and more environmentally friendly handling to reduce the negative impacts of aquaculture practices.

\section{Conclusions}

1. Litopenaeus vannamei shrimp reared in the biofloc technology (BFT) system present higher productivity and a higher survival rate than those reared in clear water.

2. Shrimp reared in clear water show oxidative damage, with reduced survival.

3. The immunological system of shrimp does not differ between rearing in clear water and in BFT.

\section{Acknowledgments}

To Ministério da Pesca e Aquicultura (MPA) and to Coordenação de Aperfeiçoamento de Pessoal de Nível Superior (Capes), for financial support; and to Conselho Nacional de Pesquisa e Desenvolvimento Científico (CNPq), for productivity research fellowships and a PhD scholarship.

\section{References}

AVNIMELECH, Y. Carbon/nitrogen ratio as a control element in aquaculture systems. Aquaculture, v.176, p.227-235, 1999.

BAUMGARTEN, M.G.Z.; ROCHA, J.M.B.; NIENCHESKI, L.F.H. Manual de análises em oceanografia química. Rio Grande: Ed. da FURG, 1996. 132p.

BENDSCHNEIDER, K.; ROBINSON, R.J. A new spectrophotometric method for the determination of nitrite in sea water. Seattle: University of Washington, 1952. Reference $\mathrm{n}^{\circ}$ 52-1. Technical Report $\mathrm{n}^{\mathrm{o}} 8$. Available at: $<$ https://digital.lib.washington. edu/researchworks/bitstream/handle/1773/15938/52-1. pdf? sequence=1>. Acessed on: Mar. 182018.

BRADFORD, M.M. A rapid and sensitive method for the quantitation of microgram quantities of protein utilizing the principle of proteindye binding. Analytical Biochemistry, v.72, p.248-254, 1976. DOI: http://doi.org/10.1016/0003-2697(76)90527-3.

BURFORD, M.A.; THOMPSON, P.J.; MCINTOSH, R.P.; BAUMAN, R.H.; PEARSON, D.C. The contribution of flocculated material to shrimp (Litopenaeus vannamei) nutrition in a highintensity, zero exchange system. Aquaculture, v.232, p.525-537, 2004. DOI: http://doi.org/10.1016/S0044-8486(03)00541-6.

CASTEX, M.; LEMAIRE, P.; WABETE, N.; CHIM, L. Effect of probiotic Pediococcus acidilactici on antioxidant defences 
and oxidative stress of Litopenaeus stylirostris under Vibrio nigripulchritudo challenge. Fish \& Shellfish Immunology, v.28, p.622-631, 2010. DOI: http://doi.org/10.1016/j.fsi.2009.12.024.

CHARRIAUT-MARLANGUE, C.; BEN-ARI, Y. A cautionary note on the use of the TUNEL stain to determine apoptosis. Neuroreport, v.7, p.61-64, 1995. DOI: https://doi.org/10.1097/00001756-199512000-00014.

CHEMICAL methods for use in marine environmental monitoring. Paris: Unesco, 1983. (Intergovernamental Oceanographic Commission. Manual and Guides, 12).

EBELING, J.M.; TIMMONS, M.B.; BISOGNI, J.J. Engineering analysis of the stoichiometry of photoautotrophic, autotrophic, and heterotrophic removal of ammonia-nitrogen in aquaculture systems. Aquaculture, v.257, p.346-358, 2006. DOI: http://doi. org/10.1016/j.aquaculture.2006.03.019.

EMERENCIANO, M.; BALLESTER, E.L.C.; CAVALLI, R.O.; WASIELESKY, W. Biofloc technology application as a food source in a limited water exchange nursery system for pink shrimp Farfantepenaeus brasiliensis (Latreille, 1817). Aquaculture Research, v.43, p.447-457, 2012. DOI: http://doi.org/10.1111/ j.1365-2109.2011.02848.x.

FAO. Food and Agriculture Organization of the United Nations. Fisheries and Aquaculture Department. The State of World Fisheries and Aquaculture: contributing to food security and nutrition for all. Rome, 2016. Available at: <http://www.fao.org/3/ i5555e/I5555E.pdf $>$. Accessed on: Mar. 102018.

FURTADO, P.S.; POERSCH, L.H.; WASIELESKY JR., W. Effect of calcium hydroxide, carbonate and sodium bicarbonate on water quality and zootechnical performance of shrimp Litopenaeus vannamei reared in bio-flocs technology (BFT) systems. Aquaculture, v.321, p.130-135, 2011. DOI: http://doi.org/10.1016/j. aquaculture.2011.08.034.

IRVINE, D.S. Glutathione as a treatment for male infertility. Reviews of Reproduction, v.1, p.6-12, 1996.

JU, Z.Y.; FORSTER, I.; CONQUEST, L.; DOMINY, W. Enhanced growth effects on shrimp (Litopenaeus vannamei) from inclusion of whole shrimp floc or floc fractions to a formulated diet. Aquaculture Nutrition, v.14, p.533-543, 2008. DOI: http://doi.org/10.1111/j.1365-2095.2007.00559.x.

KIM, S.-K.; PANG, Z.; SEO, H.-C.; CHO, Y.-R.; SAMOCHA, T.; JANG, I.-K. Effect of bioflocs on growth and immune activity of Pacific white shrimp, Litopenaeus vannamei postlarvae. Aquaculture Research, v.45, p.362-371, 2014. DOI: http://doi.org/10.1111/are.12319.

KRUMMENAUER, D.; SAMOCHA, T.; POERSCH, L.; LARA, G.; WASIELESKY JR., W. The reuse of water on the culture of Pacific white shrimp, Litopenaeus vannamei, in BFT system. Journal of the World Aquaculture Society, v.45, p.3-14, 2014. DOI: http://doi.org/10.1111/jwas.12093.

LONGARAY-GARCIA, M.; FLORES, J.A.; KÜLKAMPGUERREIRO, I.C.; GUTERRES, S.S.; PEREIRA, T.C.B.; BOGO, M. R.; MONSERRAT, J.M. Modulation of antioxidant and detoxifying capacity in fish Cyprinus carpio (Cyprinidae) after treatment with nanocapsules containing lipoic acid. Comparative
Biochemistry and Physiology, Part A, v.165, p.468-475, 2013. DOI: http://doi.org/10.1016/j.cbpa.2013.02.004.

MAGGIONI, D.S.; ANDREATTA, E.R.; HERMES, E.M.; BARRACCO, M.A. Evaluation of some hemato-immunological parameters in female shrimp Litopenaeus vannamei submitted to unilateral eyestalk ablation in association with a diet supplemented with superdoses of ascorbic acid as a form of immunostimulation. Aquaculture, v.241, p.501-515, 2004. DOI: http://doi.org/10.1016/ S0044-8486(03)00530-1.

MARTINS, A.C. da S.; FLORES, J.; PORTO, C.; WASIELESKY JUNIOR, W.; MONSERRAT, J.M. Antioxidant and oxidative damage responses in different organs of Pacific white shrimp Litopenaeus vannamei (Boone, 1931) reared in a biofloc technology system. Marine and Freshwater Behaviour and Physiology, v.48, p.279-288, 2015. DOI: http://doi.org/10.1080/1 0236244.2015.1041240.

OAKES, K.D.; VAN DER KRAAK, G.J. Utility of the TBARS assay in detecting oxidative stress in white sucker (Catostomus commersoni) populations exposed to pulp mill effluent. Aquatic Toxicology, v.63, p.447-463, 2003. DOI: http://doi.org/10.1016/ S0166-445X(02)00204-7.

RAY, A.J.; DRURY, T.H.; CECIL, A. Comparing clear-water RAS and biofloc systems: shrimp (Litopenaeus vannamei) production, water quality, and biofloc nutritional contributions estimated using stable isotopes. Aquacultural Engineering, v.77, p.9-14, 2017. DOI: http://doi.org/10.1016/j.aquaeng.2017.02.002.

SÖDERHÄLL, K.; SMITH, V.J. Separation of the haemocyte populations of Carcinus maenas and other marine decapods, and prophenoloxidase distribution. Developmental and Comparative Immunology, v.7, p.229-239, 1983. DOI: http://doi.org/10.1016/0145-305X(83)90004-6.

SOUZA, D.M. de; BORGES, V.D.; FURTADO, P.; ROMANO, L.A.; WASIELESKY JR., W.; MONSERRAT, J.M.; GARCIA, L. de O. Antioxidant enzyme activities and immunological system analysis of Litopenaeus vannamei reared in biofloc technology (BFT) at different water temperatures. Aquaculture, v.451, p.436-443, 2016. DOI: http://doi. org/10.1016/j.aquaculture.2015.10.006.

SOUZA, D.M. de; SUITA, S.M.; LEITE, F.P.L.; ROMANO, L.A.; WASIELESKY, W.; BALLESTER, E.L.C. The use of probiotics during the nursery rearing of the pink shrimp Farfantepenaeus brasiliensis (Latreille, 1817) in a zero exchange system. Aquaculture Research, v.43, p.1828-1837, 2012. DOI: https://doi.org/10.1111/j.1365-2109.2011.02992.x.

SOUZA, D.M. de; SUITA, S.M.; ROMANO, L.A.; WASIELESKY JR., W.; BALLESTER, E.L.C. Use of molasses as a carbon source during the nursery rearing of Farfantepenaeus brasiliensis (Latreille, 1817) in a biofloc technology system. Aquaculture Research, v.45, p.270-277, 2014. DOI: http://doi.org/10.1111/ j.1365-2109.2012.03223.x.

STRICKLAND, J.D.H.; PARSONS, T.R. A practical handbook of seawater analysis. 2nd ed. Ottawa: Fisheries Research Board of Canada, 1972. 311p. (Bulletin, 167).

VIAU, V.E.; SOUZA, D.M. de; RODRÍGUEZ, E.M.; WASIELESKY JR., W.; ABREU, P.C.; BALLESTER, E.L.C. 
Biofilm feeding by postlarvae of the pink shrimp Farfantepenaeus brasiliensis (Decapoda, Penaidae). Aquaculture Research, v.44, p.783-794, 2013. DOI: http://doi.org/10.1111/j.13652109.2011.03087.x.

WANG, W.; ZHANG, X. Comparison of antiviral efficiency of immune responses in shrimp. Fish \& Shellfish Immunology, v.25, p.522-527, 2008. DOI: http://doi.org/10.1016/j. fsi.2008.07.016.

WASIELESKY JR., W.; ATWOOD, H.; ATOKES, A.; BROWDY, C.L. Effect of natural production in a zero exchange suspended microbial floc based superintensive culture system for white shrimp Litopenaeus vannamei. Aquaculture, v.258, p.396-403, 2006. DOI: http://doi.org/10.1016/j.aquaculture.2006.04.030.

WHITE, C.C.; VIERNES, H.; KREJSA, C.M.; BOTTA, D.; KAVANAGH, T.J. Fluorescence-based microtiter plate assay for glutamate-cysteine ligase activity. Analytical Biochemistry, v.318, p.175-180, 2003. DOI: http://doi.org/10.1016/S00032697(03)00143-X.

XU, W.-J.; PAN, L.-Q. Enhancement of immune response and antioxidant status of Litopenaeus vannamei juvenile in biofloc-based culture tanks manipulating high $\mathrm{C} / \mathrm{N}$ ratio of feed input. Aquaculture, v.412-413, p.117-124, 2013. DOI: http://doi.org/10.1016/j.aquaculture.2013.07.017.

XU, W.J.; PAN, L.Q.; SUN, X.H.; HUANG, J. Effects of bioflocs on water quality, and survival, growth and digestive enzyme activities of Litopenaeus vannamei (Boone) in zerowater exchange culture tanks. Aquaculture Research, v.44, p.1093-1102, 2013. DOI: http://doi.org/10.1111/j.13652109.2012.03115.x.

ZHANG, G.-L.; ZHAO, H.-H.; ZHOU, Z.-W.; HE, Z.-J.; GUO, H.; CHEN, J.; LIU, L. The effects of reduced glutathione on growth rate and antioxidation capacity of tilapia. Journal of South China Agricultural University, v.3, p.90-93, 2007. 